Zohrab Ibrahimov,

Ph.D., Associate Professor, Azerbaijan State University of Economics, Azerbaijan

ORCID ID, 0000-0001-5520-4666

email: z.ibrahimov@unec.edu.az

Sakina Hajiyeva,

Ph.D., Associate Professor, Azerbaijan University of Tourism and Management, Azerbaijan

ORCID ID, 0000-0002-1031-9379

email: hajiyevasakina@yahoo.com

Vuqar Nazarov,

Ph.D., Associate Professor, Azerbaijan University of Tourism and Management, Azerbaijan

ORCID ID,: 0000-0001-9856-7184

email:v.nazarov@atmu.edu.az

Lamiya Qasimova,

Azerbaijan University of Tourism and Management, Azerbaijan

ORCID ID: 0000-0002-4844-3869

email: I.qasimova@atmu.edu.az

Vasif Ahadov,

Azerbaijan University of Tourism and Management, Azerbaijan

ORCID ID: 0000-0003-0003-8933

email: vasifahad@gmail.com

Correspondence author: z.ibrahimov@unec.edu.az

\title{
BANK EFFICIENCY ANALYSIS OF FINANCIAL INNOVATIONS: DEA MODEL APPLICATION FOR THE INSTITUTIONAL CONCEPT
}

Abstract. Globalization and digitization of the banking and financial market are well known. They are the trends of this decade-defining the context and efficiency of the banking business. Financial innovations introduced by new technologies have provided banks with the necessary utilities to seize the possibilities to tap into efficiency and competitive advantage gains. In this context, this study seeks to assess the overall efficiency of Azerbaijanian banks in adopting and utilizing financial innovation in providing financial products and services. The data envelopment analysis was applied to compute and compare the ability of financial intermediaries to adopt financial innovations via modern technologies efficiently. Based on the institutional value-added concept, the aggregate efficiency score for each of the 14 banking institutions was calculated. The inefficiency sources were derived from the overall technical efficiency decomposition into pure technical efficiency and scale efficiency. The results showed that only four banks had utilized financial innovations in the banking production process to increase their value-added during 2017-2019. Decomposition results further indicated that slight values of the overall technical inefficiency were caused by scale inefficiency. Thus, these banks' had the capacity for banking business value-added growth by $5-16 \%$ just by adjusting scales. Simultaneously, all significant deviations from the absolute overall technical efficiency caused by both pure technical efficiency and scale efficiency. Therefore, there is still much room for banking institutions to increase valueadded by adjusting scales and enhancing banking operations and management.

Keywords: institutional concept, banks, financial innovations, efficiency analysis, DEA model.

Introduction. Financial innovations created with the coming of the Fourth Industrial Revolution and the development of cyber-physical systems and digital technologies have gone on to become the framework and meaning of financial intermediation. The rapid development of web-based platforms,

Cite as: Ibrahimov, Z., Hajiyeva, S., Nazarov, V., Qasimova, L., \& Ahadov, V. (2021). Bank Efficiency Analysis of Financial Innovations: DEA Model Application for the Institutional Concept. Marketing and Management of Innovations, 1, 290-303. http://doi.org/10.21272/mmi.2021.1-22 
mobile-based applications and services that were used as a building tool for the banking business have prompted the fundamental changes and complete transformations of the institutional concept, which have set the stage for improved banking R\&D and marketing strategies, business process design and bank business models improvement. The last decade growth of the non-cash payments in Azerbaijan was $46 \%$ in the number of transactions and $12 \%$ in the amount of transactions (mln. manat); meanwhile, for the last year, the volume of e-commerce more than doubled. This stands for a sizable boost in financial innovation usage in banking; however, its profitability and efficiency still remain unclear.

The community of leading scholars and practitioners worldwide was puzzled by searching for an appropriate method to examine the relationship between financial innovation utilization that is based on the latest digital technologies and banking efficiency in recent years. New technologies that had escalated into financial innovations provided banks with the necessary utilities to seize the possibilities to tap into reducing costs and enhancing profits. Financial innovations adoption has improved banking service quality and convenience as it allows the bank customers to carry out most transactions rapidly and easily as well as communicate with the bank. Accordingly, the territorial network of banking branches may be reduced, thereby significantly reducing the bank operating costs. This indicates a need to understand to what extent financial innovations through improved banking services contribute to enhancing banking institutions' efficiency. In this context, this study seeks to assess the overall efficiency of Azerbaijanian banks in adopting and utilizing financial innovation in providing financial products and services. In this paper, Data Envelopment Analysis (DEA) was used in order to measure the overall technical efficiency (TE) and determine the sources of inefficiency by calculating pure technical efficiency (PTE) and scale efficiency (SE). In pursuing essential principles of the frontier analysis, the value-added concept of DEA modeling was chosen, following which both financial and non-financial variables were employed as inputs and outputs. This approach based on the mathematical programming model has allowed identifying Azerbaijanian banks that use financial innovations to enhance banking business value-added. Thus, the methodological approach taken in this study has helped to (1) measure each bank efficiency in terms of financial innovations adoption and utilization (efficiency score that indicates the distance from each bank in the sample to the frontier), (2) the overall technical efficiency decomposition into pure technical efficiency and scale efficiency, (3) the best-practice frontier, consisting of efficient banks, (4) efficiency reference set defined by efficient banks and (5) efficient targets for inefficient banks through the projection of inefficient banks to the best-practice frontier. The importance and originality of this study are that it explores the quantitative relationship between financial innovation utilization capability and value-added creation at the institutional level, namely banking institutions. Moreover, despite the DEA method being used extensively in different industrial and financial sectors for performance measurements and benchmarking analysis, no previous DEA applications to evaluate financial innovations utilization within the banking system have been found. The remaining parts of the paper proceed as follows. The second section begins by laying out the theoretical dimensions of the research and looks at how adopting banking services based on financial innovations leads to cost reduction and improvement bank efficiency and profitability. The third section is concerned with the data, inputs/outputs definitions and DEA methodology used for this study. The fourth section presents empirical research findings, focusing on the key themes about technical efficiency of Azerbaidjainian banks and sources of their inefficiency in financial innovations adoption and use. Conclusions are presented in the fifth section.

Literature Review. Economies digitization leads to more recent great attention has focused on benefits of financial innovations for the banking sector and capital markets. ATMs, POS terminals, Internet banking, phone banking, agency banking as well as smartcard applications have provided banks with the necessary utilities to seize the possibilities to tap into efficiency and competitive advantage gains. Thus far, several studies have indicated that financial innovations which facilities relationships between banking institutions and clients lead to enhanced banking performance through operational efficiency growth. To 
better understand how investments in information technology, such as hardware, software and other IT services, are reflected in improved performance, Beccalli (2007) analyzed 737 European banks over the period 1995-2000. Based on Ordinary Least Squares and Two-Stage Least Squares, the author shows that investments in information technology services from external providers such as consulting services, implementation services, training and education, support services increase main sources of revenues and leads to enhancement in accounting profits and profit efficiency. In the same vein, Jalal-karim and Hamdan (2010) claims that investment in software and hardware, the presence of a phone, internet and SMS banking, as well as the number of ATMs, defines banking institutions earnings per share, market valueadded, returns on assets and net profit margins. In more recent studies Mwange (2013) demonstrated that mobile banking helps to reduce marketing expenses and operating costs connected with staff numbers that involved in face-to-face transactions and therefore resulting in operating performance growth. Thus, the cost of investment in mobile banking and the number of mobile banking transactions demonstrate a positive impact on ROA. The impact of innovation on banks' performance also formed the central focus of a study by Akhisar et al. (2015) in which the authors found a positive impact of the number of cards issued by banks and the number of ATMs to the number of branches on ROA and ROE of developed and developing countries. This view on a positive relationship was supported by many researchers (Stoica et al., 2015; Dinh et al., 2015; Haabazoka, 2018 among others).

Rather interesting research findings were presented by Hernando and Nieto (2007), who reported reducing banking institution expenses on staff, marketing and IT but only after one year of internet banking adoption as a delivery channel. While banks' profitability enhancement will occur one and a half years in terms of ROA and after three years in terms of ROE. Similarly, Dinh et al. (2015) found that internet banking has a positive impact on banks' ROE and non-interest income but with a time lag of three years. Conversely, data from several sources have refuted either fully or partially the positive relationship of financial innovations on banking business efficiency. According to Sullivan (2000), adopting internet banking does not provide banks with any benefits in both profitability and risk management. Eleven years later, Khrawish and Al-Sa'di (2011) reported a disconnect between e-banking services and profitability in terms of ROA and ROE due to high expenses connected with such services adoption. In the same vein, Chae et al. (2014) conclude fails to influence IT capability on firm performance. The same empirical results were founded by Gupta et al. (2018) in the case of the Indian banking sector and Skvarciany et al. (2019) in the context of the Lithuanian market. The results of the research conducted by Gupta et al. (2018) show IT expenditure has no impact on banks' return on assets and profit efficiency. As noted by Skvarciany et al. (2019) there is no evidence that the number of POS influences the profitability of commercial banks. In most cases, such findings were explained by the presence of a productivity paradox. Given all that has been mentioned so far, one may suppose that there is mixed evidence of the financial innovations' adoption and utilization impact on banking institutions' overall performance. Nevertheless, the latest researches seem to find a positive influence. Therefore, as the intensity in the usage of financial innovations increases, competitiveness and financial performance are likely to enhance. To complement this evidence, this study by applying the output DEA model assesses the overall efficiency of Azerbaijanian banks in adopting and utilizing financial innovation in providing financial products and services, i.e., ecommerce, cashless payments by plastic cards, POS-terminals use, possibilities of money transfers via electronic network or devices, at different time horizons.

Methodology and research methods. Different authors have measured bank efficiency and performance in various ways (Brychko and Semenog, 2018). Traditionally, bank efficiency has been measured in two different ways. The first approach is based on the use of a group of absolute and relative indices. To perform a diagnostic with this coefficient analysis is relatively simple and fast, both in terms of the calculation procedure and further explanation of the received results. An additional advantage of this method is that it is based on well-known ratios that characterize the banking business profitability and are 
built on banking institutions' financial statements. Among the most popular financial ratios and indicators are the following: return on assets (ROA), net interest margin (NIM), cost-to-income ratio (CIR), return on equity (ROE), etc. The main criticism of this approach is based on the fact that the dynamics of these ratios or the absolute size of the net profit components does not sufficiently objectively reflect the bank efficiency in financial innovations. The second approach that will be further adapted in the current study is based on the application of economic and mathematical modelling. The most common methodological approaches in the banking field literature to measure bank efficiency were those that involve the formation of the efficiency frontier by Pareto-optimal values. In particular, Stochastic frontier analysis (SFA) developed by Aigner et al. (1977), Meeusen and van Den Broeck (1977), Battese and Corra (1977); deterministic frontier approach (DFA) introduced by Zellner and Revankar (1969); the Thick Frontier Approach (TFA) established by Berger and Humphrey (1991) were the widespread used. These approaches are called nonparametric research methods and are based on the specification of the exact functional form of the production frontier. SFA, DFA, TFA, OLS and other methods were compared in a series of studies, among others Resti (1997), Caudill (2002), Amelda and Sitanggang (2018). Another group of methods under the second approach includes non-parametric methods such as data envelopment analysis (DEA) applied by Obeid and Brychko (2017), Henriques et al. (2018), Shah et al. (2019); free disposal hull (FDH) used in Bardhan et al. (1996), Wang et al. (2019). Nevertheless, none of the proposed methods has absolute priority in research. This is due to different study targets and specifications, in a particular type of efficiency (cost efficiency, allocative efficiency, technical or Xefficiency), banking business features (intermediary, production approaches, and their modifications, including operational, profitable, etc.), strategic landmarks (an increase of initial parameters, a decrease of input parameters, a combination of two previous, without orientation).

In this research, a value-added approach of the CCR model introduced by Chames et al. (1978) was used to measure bank efficiency in terms of financial innovations adoption and use. CCR model is based on the constant return to scale in production and therefore was called Constant Returns to Scale (CRS). In other words, increasing or decreasing the inputs leads to proportional changes in the outputs. Since every bank is seeking to maximize its value-added, the output-oriented modification of the DEA model was used to determine the best-practice frontier. Thus, it is assumed that banking institutions are efficient as it is impossible to proportional increase the bank outputs (value-added reach maximum) with the given financial innovations. The technical efficiency problem was expressed by the following model:

$F(x, y \mid C, S)=\max \left(\varphi_{i}\right)$

subject to:

$$
\begin{aligned}
& \sum_{i=1}^{N} \lambda_{i} \cdot y_{m i}-\varphi_{i} \cdot y_{m i}^{*} \geq 0, m=1, \cdots, M \\
& x_{k i}^{*}-\sum_{j=1}^{N} \lambda_{i} \cdot x_{k i} \geq 0, k=1, \cdots, K \\
& \lambda_{j} \geq 0, j=1, \cdots, N
\end{aligned}
$$

where $\varphi_{i}$ is the objective functions value. Since an output modification is applied, the maximum of $\varphi i$ equals the largest possible increment of the outputs such as the bank remains in the reference technology. $\varphi i$ is scalar of output variables which shows by how many times the bank can increase the value-added of the banking business in case of using financial innovations in a technically efficient configuration; $i$ is sequential bank number ( $i \in[1 ; N], N$ - observations (number of banks in the sample)); $x_{k i}^{*}, x_{k i}$ is the observed amount of input of the k-th type of the i-th bank $(k \in[1 ; 4]) ; y_{m i}^{*}, y_{m i}$ is an observed amount of output of the $m$-th type for the $i$-th bank ( $m \in[1 ; 3]$ ); $\lambda i$ is a vector of the weights (intensity variables) of the $i$-th bank to be determined by the above programming problem. 
Calculated values of efficiency $\varphi_{i}$ are in the range from one to infinity. If, in optimality, $\varphi_{i}$ is equal to one, then the bank is efficient. That is, those that have chosen the right business strategy on financial innovation adoption and utilization, and, accordingly, is operating on the efficient frontier, is belonging to an efficient reference set, which demonstrates the best banking practice in terms of maximizing the banking business value-added. Thus, the level of technical efficiency does not look like a single integrated indicator but is determined by combining in a particular mathematical configuration of significant parameters that form it. Otherwise, if $\varphi$ is not equal to one, then the bank is inefficient, which implies that some financial, technological innovations are still not being fully penetrated or properly utilized. According to output-oriented DEA, the calculated measure of inefficiency determines the proportion by which banking institutions could increase value-added (outputs) while using the same amount of financial innovations (inputs). To simplify the obtained values interpretation, Farrell (1957) proposed the expression of technical efficiency in the form of an index efficiency (IE), which is calculated as follows:

$$
\begin{aligned}
& I E=1 / \varphi_{i}, \\
& I E \leq 1
\end{aligned}
$$

According to the CCR model, a banking institution that is operating in the best-practice frontier depicts both technical efficiency and scale efficiency. Decomposition of technical efficiency on pure technical efficiency and scale efficiency would assist in identifying the sources of bank inefficiency. Thus, the overall technical efficiency was decomposed as follows:

$$
T E=P T E \cdot S E,
$$

where $T E$ is technical efficiency calculated via CCR model also referred to as a constant return to scale (CRS); PTE is pure technical efficiency calculated by the BCC model also referred to as a variable return to scale (VRS); $S E$ is scale efficiency, that could be calculated by the ratio of CCR score of the model to BCC score of the model.

BCC model was developed by Banker et al. (1984) and was called Variable Returns to Scale (VRS). Efficiency, determined by the variable return on the scale, is called pure technical efficiency. By incorporating in CCR model (equations 1-4), an additional following constraint is as follows:

$$
\sum \lambda_{i}=1
$$

Thus, in contrast to the CCR model, the variable return to scale assumes that increasing or decreasing the inputs is not accompanied by corresponding proportional changes in the outputs. This disproportionate change is since the increase in financial innovations, such as internet banking, complicates the business processes and cybersecurity of the banking institution, as it increases its financial costs and management efforts to monitor and the administration of related risks, and, accordingly, does not always lead to an increase in the bank value-added. Graphical visualization of technical efficiency is presented in Figure 1. 


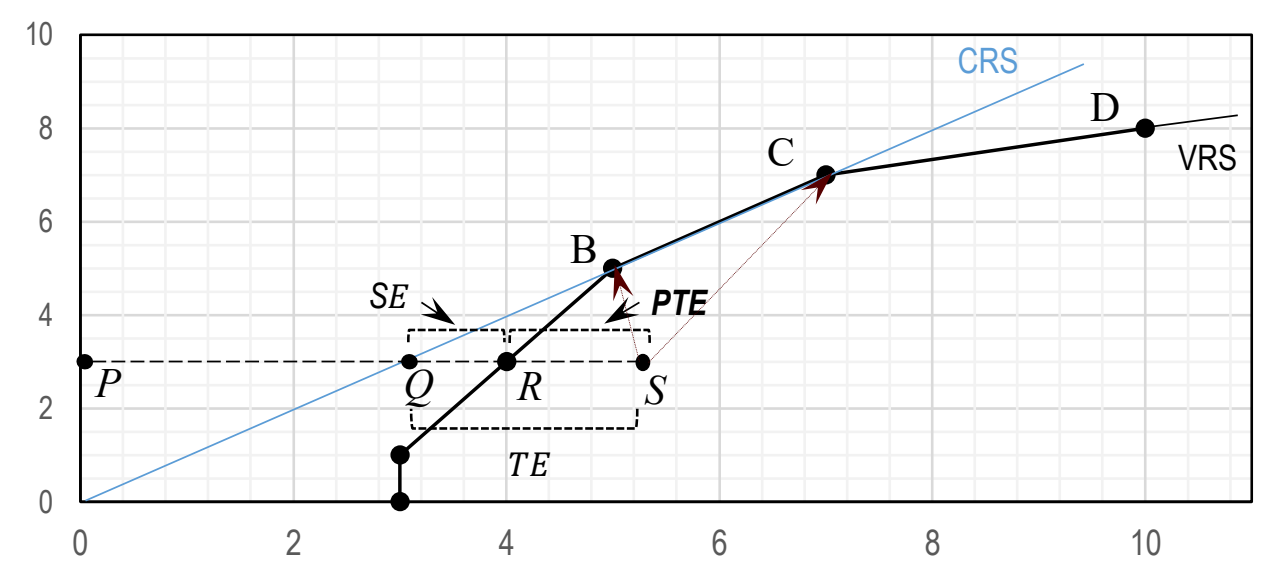

Figure 1. Graphical visualization of technical efficiency and its decomposition Sources: developed by the authors.

In Figure 1, the efficiency frontier for the CRS model is represented by a linear straight line CRS, respectively, all points $(Q, B, C)$ located on it are characterized by $100 \%$ technical efficiency of the financial innovation adoption and utilization by the banking institution. These banking institutions also have $100 \%$ pure technical efficiency and operate at the optimal scale, which ensures the profitability of banking activities. The scale efficiency of such banking institutions is equal to one. The efficiency frontier for the VRS model in Figure 1 is shown by a broken line (piecewise linear line), and, accordingly, all points ( $A, B$, C, D) located on it are characterized by $100 \%$ pure technical efficiency in terms of financial innovations utilization. However, it should be noted that points that are located at the VRS efficiency frontier, but at the same time are not at the CRS efficiency frontier $(A, D)$, is characterized by scale inefficiency. Thus, based on distances depicted in Figure 1, the technical efficiency, the pure technical efficiency and the scale efficiency could be calculated as follows:

$$
\begin{aligned}
& T E=\|P Q\|_{/\|P S\|^{\prime}} \\
& P T E=\|P R\| /\|P S\|^{\prime} \\
& S E=\|P Q\| /\|P R\|^{\prime}
\end{aligned}
$$

According to Figure 1, banking institutions $B$ and $C$ are a set of efficient reference set, that demonstrate the best practice of conducting business in terms of maximizing value-added grounded on financial innovations utilizing. For an inefficient banking institution $\mathrm{S}$, efficient targets will be set, which are the initial parameters of the banking institutions $B$ and $C$.

Efficiency analysis of financial innovations through DEA application is confronted with numerous challenges of input and output variables specification (Colwell and Davis, 1992; Berger and Humphrey, 1997). According to the institutional concept, a bank could be viewed as a financial intermediator or multiproduct firm that produces financial products and provide financial services. Thus, input and output variables specification is defined by the chosen bank behaviour model. In numerous empirical DEA studies, four approaches that represent bank behaviour models are predominant, including the 
intermediation approach (Färe and Whittaker, 1995; Chen and Yeh, 2000; Hauner, 2005), the production approach (Bergendahl, 1998; Fukuyama and Weber, 2005; Kumar and Gulati, 2008), the user cost approach (Bauer et al., 1998; Sathye, 2001) and the value-added approach (Grigorian and Manole, 2006; Pastor, 2002; Obeid and Brychko, 2017). However, these cross-sectional studies up to now have not provided any convincing explanation to justify their decision to input and output variables or DEA concept (approach) be employed. A comprehensive screening and selection inputs/outputs process is justified by the authors based on the data access issue, size of the chosen sample, banks' specific production characteristics, business model and goal system along with particular research focus and specific concerns (Ahn and Le, 2014; Stoica et al., 2015). The intermediation approach and user cost approach as complementary to the previously mentioned have become far more widely accepted and applied in DEA-based studies. The next to popularity in use is the production approach, while the use of the valueadded approach is still relatively limited.

In the case of current research, the value-added DEA approach was considered as the most beneficial since it enabling assess bank efficiency concerning its ability to utilize financial innovation to reach bank business value-added maximization, rather than in terms of its ability to mediate financial resources or produce financial products. Under the institutional concept, applied the value-added DEA approach to the current research provides a means of showing that adoption and use of financial technology innovations in banking operating activities result in boost deposits, net credits and also net profit, which are considered as significant contributions to the bank' value-added. Thus, output variables consist of the economic value added of every banking activity. At the same time, the input set consists of non-financial resources, representing financial technology innovation implemented and utilized by the banking institution. In this study, four variables to measure inputs representing adoption and utilization of financial innovations via modern technologies by banks and three variables to measure outputs denoting institutional financial performance were taken. More specifically, groups of inputs and outputs variables were set as follows: one financial input variable (volume of e-commerce operations in manats $\left(x_{1}\right)$, three non-financial input variables (number of all cashless payments by plastic cards in units $\left(\mathrm{x}_{2}\right)$, number of POS-terminals in units $\left(x_{3}\right)$, number of transfers via electronic network or devices in units $\left(x_{4}\right)$; three financial out variables (net profit $\left(\mathrm{y}_{1}\right)$, net credits $\left(\mathrm{y}_{2}\right)$, deposits $\left.\left(\mathrm{y}_{3}\right)\right)$. Due to the distinctiveness of inputs and outputs, data were gathered from multiple statistical sources. The inputs and outputs were collected on information obtained from the official site of the Central Bank of the Republic of Azerbaijan, The State Statistical Committee of the Republic of Azerbaijan, as well as annual reports of the banks in the research sample. The statistics on the input and output variables selected for Data Envelopment Analysis (DEA) were collected for 3 years, starting from 2017. The resulting data sample consists of 14 Azerbaijanian banks, which account for $70 \%$ of the total banking sector assets.

Financial innovations, as much as innovations, in general, are increasingly seen as a multidimensional phenomenon, embracing complex inter-linked dimensions. The complexity of innovation lies in the fact that what was innovation yesterday is taken for granted today. This fact left a mark on the choice of input variables to be studied. In most recent studies, financial innovations have been measured by the number of automated teller machines (ATMs), Point of Sale (POS) terminals, a volume of internet banking, telephone banking, mobile banking, agent banking operations. In contrast, several Debit \& Credit cards, free chequebooks and travel cheques that experienced a significant growth mainly from 1993 had not been considered as financial innovations as of today. Thus, financial innovations at the institution level could be reflected by a wide range of measurements that any single-dimension scale cannot estimate.

Results. For assessing bank efficiency in terms of financial innovation adoption and utilization, a value-added approach of the CCR model was used. The results obtained from the DEA efficiency analysis are presented in Figures 2-4. To simplify the obtained values interpretation, an index efficiency (IE) was used to express the overall technical efficiency (TE). 
Z., Ibrahimov, S., Hajiyeva, V., Nazarov, L., Qasimova, V., Ahadov. Bank Efficiency Analysis of Financial Innovations: DEA Model Application for the Institutional Concept

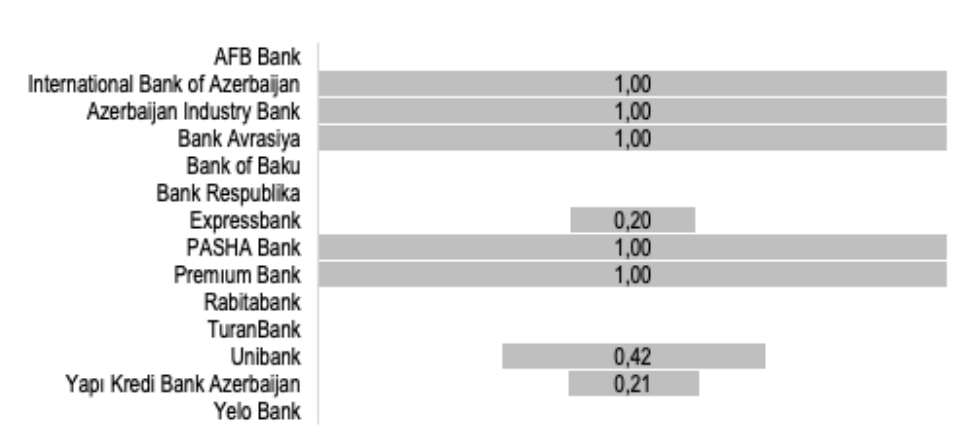

Figure 2. The overall technical efficiency of Azerbaijanian banks obtained for DEA in 2017 Sources: developed by the authors based on their calculation.

From the data in Figure 2, it is apparent that six banks from the sample, namely AFB Bank, Bank of Baku, Bank Respublika, Rabitabank, TuranBank, Yelo Bank, despite adopting and utilizing financial innovations in banking operations, remained inefficient due to the net losses obtained by the end of the year. It is apparent from this Figure that a rather large amount of inefficiency exists. The analysis results of the overall technical efficiency show a mean overall technical inefficiency is around $58 \%$. The maximum amount of inefficiency in 2017 is $80 \%$ achieved by Expressbank. Figure 2 shows that $35 \%$ (5 out 14) of banking institutions achieve the overall technical efficiency with one score. Low-efficiency scores indicate that financial innovations are not fully exploited, or their adoption leads to managerial and organizational complications of business processes resulting in operation costs increasing.

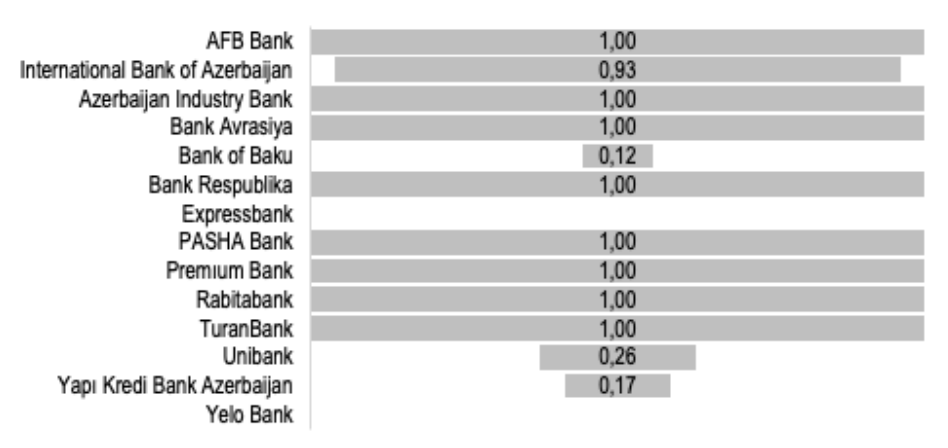

Figure 3. The overall technical efficiency of Azerbaijanian banks obtained for DEA in 2018 Sources: developed by the authors based on their calculation.

Figure 3 shows that two banks from the sample, namely Expressbank and Yelo Bank, despite adopting and utilizing financial innovations in banking operations, remained inefficient due to the net losses obtained by the end of 2018 . Further analysis showed that mean overall technical inefficiency has dropped by $26 \%$ 
since the same time the previous year. The maximum amount of inefficiency in 2018 is $88 \%$ achieved by the Bank of Baku. Data from Figure 3 can be compared with the data in Figure 2, which shows that four inefficient in 2017 banks from the sample, namely AFB Bank, Bank Respublika, Rabitabank, TuranBank, got net profit in 2018 and reached absolute overall technical efficiency concerning adopting and utilizing financial innovations. Figure 3 indicates that $57 \%$ (8 out 14) of banking institutions achieve the overall technical efficiency with one score. Also, it should be noted that the International Bank of Azerbaijan, whose were efficient in 2017, in 2018, had $93 \%$ of the overall technical efficiency. Though the overall technical inefficiency value is rather small $(7 \%)$, further analysis of inefficiency causes should be undertaken.

\begin{tabular}{|r|c|}
\hline AFB Bank & 0,95 \\
\cline { 2 - 3 } International Bank of Azerbajjan & 1,00 \\
\hline Azerbaijan Industry Bank & 1,00 \\
\hline Bank Avrasiya & 1,00 \\
\hline Bank of Baku & 0,62 \\
Bank Respublika & 1,00 \\
\hline Expressbank & 0,80 \\
\hline PASHA Bank & 1,00 \\
\hline Premium Bank & 1,00 \\
\hline Rabitabank & 0,82 \\
\hline TuranBank & 1,00 \\
\hline Unibank & 0,47 \\
\hline Yelo Bank & 0,12 \\
\hline
\end{tabular}

Figure 4. The overall technical efficiency of Azerbaijanian banks obtained for DEA in 2019 Sources: developed by the authors based on their calculation.

In Figure 4, there is a clear trend of increasing the overall technical efficiency concerning adopting and utilizing financial innovations in banking operations. The DEA CRS analysis results show that in 2019 as in the previous year, $57 \%$ (8 out 14) of banking institutions achieve the overall technical efficiency with one score. However, mean overall technical inefficiency has dropped by $43 \%$ since 2017 and has lowered two times comparing the previous year. The maximum amount of inefficiency in 2019 is still $88 \%$ but achieved by the Yapı Kredi Bank Azerbaijan. For the whole analyzed period 2017-2019, Azerbaijan Industry Bank, Bank Avrasiya, PASHA Bank and Premıum Bank were characterized by absolute overall technical efficiency that means the best practice in adopting and utilizing financial innovations while providing banking services and selling financial products. At the same time, Bank of Baku, Expressbank, Unibank and Yapı Kredi Bank Azerbaijan have represented the lowest values of the overall technical efficiency during 2017-2019 means that despite using novel financial technologies does not yield the desired results concerning the maximization of banking business value-added. In AFB Bank, the International Bank of Azerbaijan and Rabitabank have detected tiny fluctuations in the overall technical efficiency within 5-12\%. This finding stressed the need to address the root causes of banks' inefficiency concerning adopting and utilizing financial innovations in the banking business, which is achieved by decomposing the overall technical efficiency into pure technical efficiency by VRS DEA model and scale efficiency. Table 1 summarises the results obtained from the decomposition analysis of the overall technical efficiency for the whole analyzed period 2017-2019. 
Z., Ibrahimov, S., Hajiyeva, V., Nazarov, L., Qasimova, V., Ahadov. Bank Efficiency Analysis of Financial Innovations: DEA Model Application for the Institutional Concept

Table 1. Results of overall technical efficiency decomposition in 2017-2019

\begin{tabular}{|c|c|c|c|c|c|c|c|c|c|}
\hline & \multicolumn{3}{|c|}{2017} & \multicolumn{3}{|c|}{2018} & \multicolumn{3}{|c|}{2019} \\
\hline & $\mathrm{Fo}(\mathrm{x}, \mathrm{y}) \mid \mathrm{C}, \mathrm{S})$ & $\begin{array}{c}\text { Fo }(x, y) \mid \\
(V, S)\end{array}$ & So $(x, y)$ & $\mathrm{Fo}(\mathrm{x}, \mathrm{y}) \mid \mathrm{C}, \mathrm{S})$ & $\mathrm{Fo}(\mathrm{x}, \mathrm{y}) \mid \mathrm{V}, \mathrm{S})$ & So $(x, y)$ & $\mathrm{Fo}(\mathrm{x}, \mathrm{y}) \mid \mathrm{C}, \mathrm{S})$ & $\begin{array}{c}\text { Fo(x,y)| } \\
(\mathrm{V}, \mathrm{S})\end{array}$ & So $(x, y)$ \\
\hline $\begin{array}{c}\text { AFB Bank } \\
\text { International }\end{array}$ & 0,00 & 0,00 & 0,00 & 1,00 & 1,00 & 1,00 & 1,05 & 1,00 & 1,05 \\
\hline $\begin{array}{c}\text { Bank of } \\
\text { Azerbaijan }\end{array}$ & 1,00 & 1,00 & 1,00 & 1,08 & 1,00 & 1,08 & 1,00 & 1,00 & 1,00 \\
\hline $\begin{array}{l}\text { Azerbaijan } \\
\text { Industry Bank }\end{array}$ & 1,00 & 1,00 & 1,00 & 1,00 & 1,00 & 1,00 & 1,00 & 1,00 & 1,00 \\
\hline Bank Avrasiya & 1,00 & 1,00 & 1,00 & 1,00 & 1,00 & 1,00 & 1,00 & 1,00 & 1,00 \\
\hline Bank of Baku & 0,00 & 0,00 & 0,00 & 8,29 & 2,50 & 3,32 & 1,61 & 1,36 & 1,19 \\
\hline $\begin{array}{c}\text { Bank } \\
\text { Respublika }\end{array}$ & 0,00 & 0,00 & 0,00 & 1,00 & 1,00 & 1,00 & 1,00 & 1,00 & 1,00 \\
\hline Expressbank & 4,94 & 1,80 & 2,74 & 0,00 & 0,00 & 0,00 & 1,25 & 1,00 & 1,25 \\
\hline PASHA Bank & 1,00 & 1,00 & 1,00 & 1,00 & 1,00 & 1,00 & 1,00 & 1,00 & 1,00 \\
\hline Premıum Bank & 1,00 & 1,00 & 1,00 & 1,00 & 1,00 & 1,00 & 1,00 & 1,00 & 1,00 \\
\hline Rabitabank & 0,00 & 0,00 & 0,00 & 1,00 & 1,00 & 1,00 & 1,22 & 1,05 & 1,16 \\
\hline TuranBank & 0,00 & 0,00 & 0,00 & 1,00 & 1,00 & 1,00 & 1,00 & 1,00 & 1,00 \\
\hline Unibank & 2,37 & 1,98 & 1,20 & 3,85 & 2,06 & 1,87 & 2,12 & 1,55 & 1,37 \\
\hline $\begin{array}{l}\text { Yapı Kredi } \\
\text { Bank } \\
\text { Azerbaijan }\end{array}$ & 4,75 & 4,13 & 1,15 & 5,80 & 5,17 & 1,12 & 8,11 & 3,75 & 2,16 \\
\hline Yelo Bank & 0,00 & 0,00 & 0,00 & 0,00 & 0,00 & 0,00 & 1,00 & 1,00 & 1,00 \\
\hline
\end{tabular}

Notes: $\mathrm{Fo}(\mathrm{x}, \mathrm{y}) \mid \mathrm{C}, \mathrm{S})$ stands for the overall technical efficiency by CRS DEA model $(\mathrm{TE}), \mathrm{Fo}(\mathrm{x}, \mathrm{y}) \mid \mathrm{V}, \mathrm{S})$ means the pure technical efficiency calculated by VRS DEA model (PTE), So(x,y) represents scale efficiency computed as the ratio between the overall technical efficiency and the pure technical efficiency (SE).

Sources: developed by the authors based on their calculation.

In Table 1, the single most striking observation to emerge from the data comparison is that slight values of the overall technical inefficiency were caused by banks' scale inefficiency. International Bank of Azerbaijan, AFB Bank and Rabitabank are already in the efficiency frontier created based on the VRS DEA model that means using the best practices of financial innovations adoption and utilization. Nonetheless, in 2018 scale efficiency of the International Bank of Azerbaijan was equal to 1.08; in 2019 scale efficiency of AFB Bank and Rabitabank were respectively 1.05 and 1.16. This demonstrates banks' inability to achieve the same value-added due to economies of scale. Thus, just by adjusting scales, these banks' had the capacity for banking business value-added growth by 8,5 and $16 \%$.

All significant deviations from the absolute overall technical efficiency that is equal to one have been demonstrated by Unibank, Yapı Kredi Bank Azerbaijan, Bank of Baku and Expressbank caused by banks' both pure technical inefficiency and scale inefficiency. Pure technical inefficiency derived from the efficiency index varies from 26 to $81 \%$ for the whole analyzed period and is caused by inefficient banking operations and management. Simultaneously, scale inefficiency fluctuates from 11 to $70 \%$ that resulted from disadvantageous conditions displayed by the scale efficiency (SE).

Conclusions. Banking institutions worldwide have indeed benefited enormously from the introduction of cyber-physical systems and digital technologies into the financial sphere. Financial innovations radically have changed channels and how banking institutions provide financial services and produce financial 
products according to clients' demands and expectations. Despite the upsurge of web-based platforms, mobile-based applications and services in banking intermediation, the problem addressed the impact of financial innovations adoption and utilization has received scant attention in the research literature.

This study was undertaken to design a proper methodology and evaluate the overall efficiency of Azerbaijanian banks in adopting and utilizing financial innovation in providing financial products and services to enhance banking business value-added. To be able to address this purpose, based on the value-added Data Envelopment Analysis, the overall technical efficiency (TE) was measured. The inefficiency sources were derived from the overall technical efficiency decomposition into pure technical efficiency (PTE) and scale efficiency (SE). The importance and originality of this study are that it explores the quantitative relationship between financial innovation utilization capability and value-added creation at the institutional level, namely banking institutions.

This study has found that generally several banks from the sample, despite adopting and utilizing financial innovations in banking operations, remained inefficient due to the net losses obtained by the end of the year. This study has identified a positive trend noted more recently towards the drop in the mean overall technical inefficiency from $58 \%$ in 2017 to $16 \%$ in 2019. The findings indicate that in 2017 only $35 \%$ (5 out 14) of banking institutions achieve the overall technical efficiency with one score, while in 2018 and 2019 , this value had yielded $57 \%$ (8 out 14). This study has identified the best-practice frontier and efficiency reference set consisting of absolute efficient banks for the whole analyzed period 2017-2019, namely Azerbaijan Industry Bank, Bank Avrasiya, PASHA Bank and Premıum Bank. Outlined banking institutions banks are leaders and benchmarks for inefficient banks in adopting and utilizing financial innovations through providing banking services and selling financial products. At the same time, Bank of Baku, Expressbank, Unibank and Yapı Kredi Bank Azerbaijan have represented the lowest overall technical efficiency values during 2017-2019. Those banking institutions are outsiders who, despite using novel financial technologies, do not yield the desired results concerning the maximization of banking business value-added.

One of the more significant findings to emerge from this study is that slight values of the overall technical inefficiency were caused by scale inefficiency, i.e., banking institutions are is over/underdimensioned. Thus, just by adjusting scales, these banks' had the capacity for banking business valueadded growth by 8,5 and $16 \%$. Simultaneously, all significant deviations from the absolute overall technical efficiency caused by inefficient banking operations and management (PTE) and disadvantageous conditions were displayed by the scale efficiency (SE).

Although the current study is based on a small sample of banking institutions, this study offers some insight into DEA efficiency analysis of adopting and providing banks client with e-commerce, cashless payments by plastic cards, POS-terminals use, possibilities of money transfers via electronic network or devices. This study results can be used to develop targeted interventions for inefficient banking institutions aimed at enhancement of banking business value-added based on financial innovations adoption and utilization. Considerably more work will need to be done to determine efficient targets for each inefficient bank from the sample that could be done based on benchmarks analysis.

Author Contributions: conceptualization and methodology, Z. I. and S. H.; software, V. N.; validation, Z. I., S. H. and L. Q.; formal analysis and investigation, Z. I., S. H. and V. A.; resources, data curation, writing-original draft preparation, writing-review and editing, Z. I., S. H., V. N., L. Q. and V. A.; visualization,Z. I.; supervision, S. H., V. N., L. Q. and V. A; project administration, Z. I. 


\section{References}

Ahn, H., \& Le, M. H. (2014). An insight into the specification of the input-output set for DEA-based bank efficiency measurement. Management Review Quarterly, 64(1), 3-37. [Google Scholar] [CrossRef]

Aigner, D., Lovell, C. K., \& Schmidt, P. (1977). Formulation and estimation of stochastic frontier production function models. Journal of econometrics, 6(1), 21-37. [Google Scholar] [CrossRef]

Akhisar, I., Tunay, K. B., \& Tunay, N. (2015). The effects of innovations on bank performance: The case of electronic banking services. Procedia-Social and Behavioral Sciences, 195, 369-375. [Google Scholar] [CrossRef]

Akimova, L. M., Akimov, O. O., \& Liakhovich, O. O. (2017). State regulation of foreign economic activity. Scientific bulletin of Polissia, 1 (4 (12)), 98-103.. [Google Scholar]

Akimova, L., Akimov, O., Mihus, I., Koval, Y., \& Dmitrenko, V. (2020). Improvement of the methodological approach to assessing the impact of public governance on ensuring the economic security of the state. Financial and credit activity: problems of theory and practice, 4(35), 180-190. [Google Scholar]

Amelda, B., \& Sitanggang, E. B. (2018). Analysis of Banking Industry Performance Efficiency in Indonesia Using Parametric and Nonparametric Methods. The Winners, 19(1), 53-67. [Google Scholar] [CrossRef]

Banker, R. D., Charnes, A., \& Cooper, W. W. (1984). Some models for estimating technical and scale inefficiencies in data envelopment analysis. Management science, 30(9), 1078-1092. [Google Scholar] [CrossRef]

Baranovskyi, O. I. (2020). Regulation of functional and structural transformational processes in the financial sector. Financial and credit activity: problems of theory and practice, 1(32), 292-306. [Google Scholarl [CrossRef]

Bardhan, I., WF, B., WW, C., \& Sueyoshi, T. (1996). Models and measures For efficiency dominance in DEA Part II: Free disposal hull (FDH) and Russel measure (RM) approaches. Journal of the Operations Research Society of Japan, 39(3), 333-344. [Google scholar] [CrossRef]

Battese, G. E., \& Corra, G. S. (1977). Estimation of a production frontier model: with application to the pastoral zone of Eastern Australia. Australian journal of agricultural economics, 21(3), 169-179. [Google Scholar] [CrossRef]

Bauer, P. W., Berger, A. N., Ferrier, G. D., \& Humphrey, D. B. (1998). Consistency conditions for regulatory analysis of financial institutions: a comparison of frontier efficiency methods. Journal of Economics and business, 50(2), 85-114. [Google Scholar] [CrossRef

Beccalli, E. (2007). Does IT investment improve bank performance? Evidence from Europe. Journal of banking \& finance, 31(7), 2205-2230. [Google Scholar] [CrossRef]

Bergendahl, G. (1998). DEA and benchmarks-an application to Nordic banks. Annals of Operations Research, 82, 233-250. [Google Scholar] [CrossRef]

Berger, A. N., \& Humphrey, D. B. (1991). The dominance of inefficiencies over scale and product mix economies in banking. Journal of Monetary Economics, 28(1), 117-148. [Google Scholar] [CrossRef]

Berger, A. N., \& Humphrey, D. B. (1997). Efficiency of financial institutions: International survey and directions for future research. European journal of operational research, 98(2), 175-212. [Google Scholar] [CrossRef]

Brychko, M., \& Semenog, A. (2018). Efficiency as a new ideology of trust-building corporate governance. Business and Economic Horizons (BEH), 14(4). [Google Scholar]

Caudill, S. B. (2002). SFA, TFA and a new thick frontier: graphical and analytical comparisons. Applied Financial Economics, 12(5), 309-317. [Google Scholar] [CrossRef]

Chae, H. C., Koh, C. E., \& Prybutok, V. R. (2014). Information technology capability and firm performance: contradictory findings and their possible causes. MIS quarterly, 38(1), 305-326. [Google Scholar]

Chames, A., Cooper, W. W., \& Rhodes, E. (1978). Measuring the efficiency of decision making units. European journal of operational research, 2(6), 429-444. [Google Scholar] [CrossRef]

Chen, T. Y., \& Yeh, T. L. (2000). A Measurement of Bank Efficiency, Ownership and Productivity Changes in Taiwan. The Service Industries Journal, 20(1), 95-109. [Google Scholar] [CrossRef]

Colwell, R. J., \& Davis, E. P. (1992). Output and productivity in banking. The Scandinavian Journal of Economics, 111-129. [Google Scholar] [CrossRef]

Dinh, V., Le, U., \& Le, P. (2015). Measuring the impacts of internet banking to bank performance: Evidence from Vietnam. The Journal of Internet Banking and Commerce, 20(2). [Google Scholar]

Färe, R., \& Whittaker, G. (1995). An intermediate input model of dairy production using complex survey data. Journal of Agricultural Economics, 46(2), 201-213. [Google Scholar] [CrossRef]

Farrell, M. J. (1957). The measurement of productive efficiency. Journal of the Royal Statistical Society: Series A (General), 120(3), 253-281. [Google Scholar] [CrossRef]

Fukuyama, H., \& Weber, W. L. (2005). Estimating output gains by means of Luenberger efficiency measures. European Journal of Operational Research, 164(2), 535-547. [Google Scholar] [CrossRef]

Girchenko, T. D., Panchenko, O.V. (2020). Research on the practical aspects of the providing efficiency of marketing communications' bank. Financial and credit activity-problems of theory and practice, 3. P. 13-22. [CrossRef]

Grigorian, D. A., \& Manole, V. (2006). Determinants of commercial bank performance in transition: An application of data envelopment analysis. Comparative Economic Studies, 48(3), 497-522. [Google Scholar] [CrossRef] 
Z., Ibrahimov, S., Hajiyeva, V., Nazarov, L., Qasimova, V., Ahadov. Bank Efficiency Analysis of Financial Innovations: DEA Model Application for the Institutional Concept

Gupta, S. D., Raychaudhuri, A., \& Haldar, S. K. (2018). Information technology and profitability: evidence from Indian banking sector. International Journal of Emerging Markets, 13(5), 1070-1087. [Google Scholar] [CrossRef]

Haabazoka, L. (2018). A Study of the Effects of Technological Innovations on the Performance of Commercial Banks in Developing Countries - A Case of the Zambian Banking Industry. Lecture Notes in Networks and Systems, 1246-1260. [Google Scholar] [CrossRef]

Hauner, D. (2005). Explaining efficiency differences among large German and Austrian banks. Applied economics, 37(9), 969980. [Google Scholar] [CrossRef]

Henriques, I. C., Sobreiro, V. A., Kimura, H., \& Mariano, E. B. (2018). Efficiency in the Brazilian banking system using data envelopment analysis. Future Business Journal, 4(2), 157-178. [Google Scholar] [CrossRef]

Hernando, I., \& Nieto, M. J. (2007). Is the Internet delivery channel changing banks' performance? The case of Spanish banks. Journal of Banking \& Finance, 31(4), 1083-1099. [Google Scholar] [CrossRef]

Jalal-Karim, A., \& Hamdan, A. M. (2010). The impact of information technology on improving banking performance matrix Jordanian banks as case study. European Mediterranean and Middle Eastern Conference on Information System, 21-33. [Google Scholar]

Karpa, M. I., Akimova, L. M., Akimov, O. O., Serohina, N., Oleshko, O., \& Lipovska, N. (2021). Public administration as a systemic phenomenon in society. AD ALTA: Journal of interdisciplinary research, (11), 56-62. [Google Scholar]

Khrawish, H. A., \& Al-Sa'di, N. M. (2011). The impact of e-banking on bank profitability: Evidence from Jordan. Middle Eastern Finance and Economics, 13(1), 142-158. [Google Scholar]

Kumar, S., \& Gulati, R. (2008). Evaluation of technical efficiency and ranking of public sector banks in India. International Journal of Productivity and Performance Management, 57(7), 540-568. [Google Scholar] [CrossRef]

Meeusen, W., \& van Den Broeck, J. (1977). Efficiency estimation from Cobb-Douglas production functions with composed error. International economic review, 435-444. [Google Scholar] [CrossRef]

Mwange, J. A. (2013). The impact of mobile banking on financial performance of commercial banks in Kenya. Master's Thesis, University of Nairobi, Nairobi. [Google Scholar]

Ngari, M. J.,\& Muiruri, K. J.(2014).Effects of financial innovation on the financial performance of commercial banks in Kenya. International Journal of Humanities and Social Sciences, 4(7), 51-57. [Google Scholar]

Obeid, H., \& Brychko, M. (2017). Stakeholder's financial relations and bank business management efficiency: evidence from Ukraine. Financial Markets, Institutions and Risks, 1(2), 12-29. [Google Scholar] [CrossRef]

Pastor, J. M. (2002). Credit risk and efficiency in the European banking system: A three-stage analysis. Applied Financial Economics, 12(12), 895-911. [Google Scholar] [CrossRef]

Resti, A. (1997). Evaluating the cost-efficiency of the Italian banking system: What can be learned from the joint application of parametric and non-parametric techniques. Journal of banking \& finance, 21(2), 221-250. [Google Scholar] [CrossRef]

Sathye, M. (2001). X-efficiency in Australian banking: An empirical investigation. Joumal of Banking \& Finance, 25(3), 613-630 [Google Scholar] [CrossRef]

Shah, A. A., Wu, D., \& Korotkov, V. (2019). Are sustainable banks efficient and productive? A data envelopment analysis and the Malmquist productivity index analysis. Sustainability, 11(8), 2398. [Google Scholar] [CrossRef]

Simionescu, M., Strielkowski, W., \& Kalyugina, S. (2017). The impact of Brexit on labour migration and labour markets in the United Kingdom and the EU. Terra Economicus, 15(1), 148-156. [Google Scholar] [CrossRef]

Skvarciany, V., Jurevičienè, D., \& Morkunas, M. (2019). Determinants of bank profitability: empirical research on Lithuanian market. International Journal of Economic Policy in Emerging Economies, 12(5), 443-452. [Google Scholar] [CrossRef]

Stoica, O., Mehdian, S., \& Sargu, A. (2015). The impact of internet banking on the performance of Romanian banks: DEA and PCA approach. Procedia Economics and Finance, 20, 610-622. [Google Scholar] [CrossRef]

Strielkowski, W., \& Höschle, F. (2016). Evidence for economic convergence in the EU: The analysis of past EU enlargements. Technological and Economic Development of Economy, 22(4), 617-630. [Google Scholar] [CrossRef]

Strielkowski, W., \& Höschle, F. (2016). Evidence for economic convergence in the EU: The analysis of past EU enlargements. Technological and Economic Development of Economy, 22(4), 617-630. [Google Scholar] [CrossRef]

Sullivan, R. J. (2000). How has the adoption of Internet banking affected performance and risk in banks?. Financial Industry Perspectives, 12(1), 16. [Google Scholar]

Vovchak, O. D., Senyshch, P. M., \& Melnyk, T. V. (2019). «Purging» of the banking system: impact on the key performance indicators of banks. Financial and credit activity: problems of theory and practice, 1(28), 16-25. [Google Scholar] [CrossRef]

Wang, X, Fu, P., \& Tian, Y. (2019). Research on the Efficiency of Commercial Banks in China: Based on Two-Stage FDH Method. SSRN Electronic Journal. [Google Scholar] [CrossRef]

Zahorskyi, V. S., Lipentsev, A. V., Yurystovska, N. Y., Mazii, N. H., \& Akimov, O. O. (2019). Financial and administrative aspects of small business development in Ukraine. Financial and credit activity: problems of theory and practice, 3(30), 351-360. [Google Scholar]

Zellner, A., \& Revankar, N. S. (1969). Generalized production functions. The Review of Economic Studies, 36(2), 241-250. [Google Scholar] [CrossRef] 
Z., Ibrahimov, S., Hajiyeva, V., Nazarov, L., Qasimova, V., Ahadov. Bank Efficiency Analysis of Financial Innovations: DEA Model Application for the Institutional Concept

Зограб Ібрагімов, Ph.D., доцент, Азербайджанський Державний Економічний Університет, Азербайджан

Сакіна Гаджиєва, Ph.D., доцент, Азербайджанський Університет Туризму і Менеджменту, Азербайджан

Вукар Назаров, Ph.D., доцент, Азербайджанський Університет Туризму і Менеджменту, Азербайджан

Ламія Гасимова, Азербайджанський Університет Туризму і Менеджменту, Азербайджан

Васіф Ахадов, Азербайджанський Університет Туризму і Менеджменту, Азербайджан

Аналіз банківської ефективності впровадження фінансових інновацій: застосування моделі DEA для інституційної концепції

Впровадження кіберфізичних систем та цифрових технологій у фінансову сферу сприяли значному розвитку банківських установ у всьому світі. Фінансові інновації докорінно змінили канали та спосіб надання фінансових послуг банківськими установами та виробництва фінансових продуктів відповідно до вимог та очікувань клієнтів. Однак, попри стрімкий розвиток популярності вебплатформ, мобільних додатків та послуг у банківському секторі, серед науковців залишається невирішеною проблемою визначення наслідків впровадження та використання фінансових інновацій. Метою даного дослідження $\epsilon$ розробка методологічного підходу та оцінка загальної ефективності впровадження та використання фінансових інновацій при наданні фінансових продуктів та послуг для підвищення доданої вартості банківського бізнесу. Емпіричне дослідження проведено на основі панельних даних, сформованих для вибірки з 14 банків Азербайджану за 2017-2019 рр. Для досягнення поставленої мети, у роботі побудовано DEA модель з орієнтацією на максимізацію доданої вартості. За отриманими результатами було встановлено загальну технічну ефективність впровадження фінансових інновацій. Автори визначили джерела неефективності за допомогою декомпозиції технічної ефективності на технічну ефективність та ефективність масштабу. Таким чином, отримані результати свідчать про зниження середньої загальної технічної неесективності $358 \%$ у 2017 році до 16\% у 2019 році. Результати дослідження засвідчили, що лише чотири банки впровадили фінансові інновації 3 метою максимізації доданої вартості. При цьому зазначені банківські установи є лідерами у своїй галузі, що свідчить про доцільність впровадження та використання фінансових інновацій при наданні банківських послуг та продажу фінансових продуктів. За результатами дослідження встановлено, що незначні значення загальної технічної неефективності були спричинені неефективністю масштабу. При цьому встановлено, що значні відхилення від абсолютної загальної технічної ефрективності були спричинені неефективністю банківських операцій та невигідними умовами в наслідок неадекватного масштабу. Таким чином, за результатами дослідження автори прийшли до висновку, що збільшення доданої вартості банківського бізнесу на 5-16\% можливе за допомогою підвищення ефективності масштабу.

Ключові слова: аналіз ефективності, банк, інституційна концепція, модель DEA, фінансові інновації. 